\title{
Development Model of Perinatal Death Surveilance and Response (PDSR) in Semarang City, Indonesia
}

\author{
Sutopo Patria Jati*, Rani Tiyas Budiyanti*, Nikie Astorina Yunita Dewanti*, Ayun Sriatmi*, Martini* \\ * Correspondence Author: ranitiyasbudiyanti@gmail.com \\ *Public Health Faculty, Diponegoro University, Semarang, Indonesia
}

\section{N D E X I N G \\ Keywords:}

Perinatal Death Record;

Perinatal Death Report;

Semarang;

\section{Kata Kunci:}

Pencatatan Angka

Kematian Perinatal;

Pelaporan Angka

Kematian Perinatal;

Semarang;

\begin{abstract}
A B S T R AC T
The infant mortality rate is the important things to measure health status and achievement of Sustained Development Goals (SDGs). It can be used to audit the cause of perinatal death and used to planning program to prevent the death. In addition, data on perinatal deaths must be recorded in terms of population administration. The problem is underreported perinatal death so that data not valid. This is because many government stakeholder such as Health Office, Administrative Village, Family Empowerment and Welfare (PKK), and the Information and Communication Department has reported and recorded perinatal death themself but not integrated. This study aims to develop a concept of integrated perinatal death report and record. This research is qualitative research with following steps advocation, initial assessment, and development models through interview, observation, and Focus Group Discussion methods. The result of this study is existing condition and concept model that can integrate of perinatal death record and reported. The concept model in Semarang City, Indonesia can be done in two ways. First, data comes from the Health Office (SIM-KIA). Second, data comes from Administrative Village and Family Empowerment and Welfare (PKK). All of the data forwarded to the Integrated Data Integration System (SIDADU) in Information and Communication Service in Semarang City. To support the validity of data, the Health Office should identify all public and private health facilities related to perinatal care. The local government should release Circular Letter concerning the notification of services regarding the recording and reporting of perinatal deaths in Administrative Village.
\end{abstract}

Angka kematian bayi dan perinatal merupakan salah satu indikator penting untuk menilai derajat
kesehatan dan pencapaian Sustained Development Goals (SDGs). Angka tersebut dapat digunakan
sebagai perencanaan program untuk mencegah kematian bayi dan perinatal. Selain itu, data kematian
perinatal juga perlu dilaporkan dalam hal administasi kependudukan. Salah satu permasalahan yang
terjadi adalah adanya kematian perinatal yang tidak dilaporkan (underreported) sehingga data yang
diperoleh tidak valid. Hal ini dikarenakan data mengenai kematian perinatalyang diperoleh dari sektor
terkait seperti Dinas Kesehatan, Kelurahan, PKK, Dinas Kependudukan dan Pencatatan Sipil, serta
Dinas Komunikasi dan Informatika tidak terintegrasi. Penelitian ini bertujuan untuk mengembangkan
konsep model pencatatan dan pelaporan kematian perinatal (PDSR) yang terintegrasi. Penelitian ini
adalah penelitian kualitatif melalui tahapan advokasi, analisis kebutuhan, dan pengembangan model
dengan metode wawancara, observasi, dan Focus Group Discussion (FGD). Model integrasi pencatatan
dan pelaporan kematian perinatal di Kota Semarang dapat dilakukan melalui dua alur. Pertama, data
diperoleh dari Dinas Kesehatan. Kedua, data diperoleh dari Kelurahan dan PKK. Keseluruhan data akan
diintegrasikan melalui Sistem Integrasi Data Terpadu (SIDADU) yang dikelolah oleh Dinas Komunikasi
dan Informasi sebagai wali data. Untuk mendukung validitas data, Dinas Kesehatan sebaiknya
mengidentifikasi semua fasilitas kesehatan baik publik maupun swasta yang berkaitan dengan perawatan
perinatal. Selain itu, Pemerintah Daerah sebaiknya mengeluarkan Surat Edaran mengenai kewajiban
untuk mencatat dan melaporkan kematian perinatal di Kelurahan.

Article history: Received 2019-Jan-14; Revised 2019-Apr-04; Accepted 2019-Apr-12

\section{INTRODUCTION}

Valid recording and reporting of infant or perinatal mortality important to evaluate and plan programs that can reduce the mortality. - It is also the important thing to measure the achievement of Sustained Development Goals (SDGs). ${ }^{2}$ In Indonesia, in addition to being a health problem, recording and reporting perinatal deaths (infants aged 7 months in the womb until the baby is born to 28 days old) also needs to be done in terms of Population and Civil Registration. Infant death especially still birth must be reported.

Responsibility of reporting and recording of infant mortality based on Article 33 of Law Number 23 the year 2006 on Population Administration that states " Every stillborn baby must be reported by the population to the Implementing Agency and issued a certificate of stillbirth."
This regulation was supported by a Joint Regulation between Minister of Home Affairs and Minister of Health Number 15 year 2010 and Number 162/MOH/PB/I year 2010 on Reporting of Deaths and Causes of Death. ${ }^{4}$

In Semarang City, a city in Central Java, Indonesia, there is no integrated data of reporting and recording data between government stakeholder such as Health Office, Department of Population and Civil Registration, Family Empowerment and Welfare (PKK), Administrative Village. The stakeholders have reported and recorded perinatal death themselves but not integrated.

Although there is regulation about recording and reporting perinatal mortality that was accordance by Mayors Regulation in Semarang City Number 40 year 2017 that 
concern of Integrated Data Information System (SIDADU), but the reality is difficult to ask the data from the stakeholder. So that, its need an alternative model to integrated data from government stakeholder.

\section{RESEARCH METHOD}

This research is qualitative research with interview, observation, and Focus Group Discussion methods. It was held in Semarang City, Indonesia at September until November 2018 with the following steps: initial advoaction, assessment, and development model of PDSR. Initial advocation was held in Semarang through discussion with Maternal and Child Deprtment of Health Office, Head of Department of Population and Civil Registration, and Head of Family Empowrment and Welfare (PKK). This activity aims to introduce the program and to identify the challenge and general problems to have the valid perinatal mortality data. With this advocacy, it is expected that the recording and reporting of integrated perinatal deaths will receive support from multi-stakeholders or related sectors.

Initial assessment was done in Health Office, Department of Population and Civil Registration, Family Empowrment and Welfare (PKK), Administrative Village, and Information and Communication Service in Semarang City through observation and interview. This activity aims to identify the existing condition of reporting and recording perinatal/infant mortality, challenge and spesific problems to have the reliable and valid perinatal mortality data. Interviews were conducted with Maternal and Child Department of Health office, Head of the Population and Civil Registry Office, the Chairman of the Family Empowerment and Welfare (PKK), and the development team for one data in the Communication and Informatics Department.

Focuss Group Discussion was held in Semarang City between Health Office, Department of Population and Civil Registration, Family Empowrment and Welfare (PKK), Administrative Village, and Information and Communication Service in Semarang City and other stakeholder such as Social Security Administrator (BPJS), Hospital, Primary Health Care, Sub District Administrator, and Regional Planning and Development Agency. The number of focus group discussion participants was 20 people. This activity aims to identify the problem in reporting and recording perinatal/infant mortality, and to define the draft and concept model to integrate infant mortality data. Development model was build after focus group discussion. This activity was held to finalized the recommendation and alternative model that can be applied in Semarang City.

\section{RESULT AND DISCUSSION}

Existing Condition of Reporting and Recording of Infant Mortality

\section{Reporting and Recording in Health Office}

Recording and reporting of perinatal death at Health Office was obtained from the health facility reports such as independent practice midwives, clinics/maternity hospital, health centers, public and private hospital. This activity also supported by Health Surveilence Officers (Gasurkes) in the
Health of Maternity and Child. In Semarang City, the Health Office has developed Maternity and Child Management Information System (SIM-KIA). There isnt synchronize and integrate between Health Office and other stakeholder to verified the data.

"...Recording and reporting of perinatal deaths in Semarang City through the maternal and child health information system (SIM-KIA). However,it is still necessary to identifiy private health facilities and hospitals and encourage reporting of perinatal deaths to health office ..."

\section{Reporting and Recording in Department of Population and Civil Registration}

Department of Population and Civil Registration has a service for reporting perinatal/ still birth death, but its passive activity (just waiting for reporting). There is a special form to report perinatal death namely Form 2.08 for Indonesia citizens and Form 2.10 for foreigners. At present, there is no reporting of perinatal deaths and no perinatal death data in Department of Population and Civil Registration in Semarang City, although this is mandatory. There is also no online service reporting that was provided.

“...Reporting of perinatal deaths in terms of population in Semarang City is passive, Population and Civil Registry Service is waiting for reports from the public. Even so, until now, there have been no reports regarding perinatal deaths. Although there is already a form provided..."

\section{Reporting and Recording in Administrative Village}

Reporting and recording of perinatal deaths at Adiministrative Village (Kelurahan) level has not reported well because many administrative village have not yet known about obligation and procedures for reporting perinatal deaths. They also never issued a Certificate to Stillbirth or Perinatal Death. This also because communities often not reporting the perinatal death and not asking for Stillbirth / Perinatal Death Certificate. Despite of in the administrative village, there is administration and management information system that called SI-EMAK that has been implemented to record all administration, but there is no reporting of perinatal death.

“...During this time the administrative village did not know about the obligation to report perinatal deaths, especially stillbirths, and to date no community has reported to administration. So, until now the administrative village has never issued a certificate of stillbirth..."

\section{Reporting and Recording in Family Empowrment and Welfare}

Reporting and recording of perinatal deaths in Family Empowrment and Welfare (PKK) is well supported by networks that are close to the community. PKK incude of Services for Womans Empowrment and Child Protection. PKK has a Registration Book with columns related to data on babies born, died, pregnant women, and childbirth that are 
update regularly and periodically. The data obtained will be reported to PKK at Sub-District, District, City, Province, and National levels. There has been no data synchronization with the Health Office and Department of Population and Civil Registration.

“....Family Empowerment and Welfare (PKK) has detailed records of data on infant mortality, maternal pregnancy, stillbirth, etc. which are regularly updated. Reporting is carried out in stages from the regional to the central level. Until now, data from Family Empowerment and Welfare (PKK) have not been synchronized with other related parties...."

Reporting and Recording in Information and Communication Service

Currently an Integrated Data Information System (SIDADU) is being developed that integrates data from various stakeholder including data on perinatal deaths. SIDADU will be integrated with " One Data" at National level. Information and Communication Services acts as a data guardian who collects, process and presents integrated data from data providers (PKK, Health Office, Administrative village, and Health Office). But until now, its difficult to ask data from many stakeholder because there are no technical instructioms from the Mayor Regulations regarding SIDADU.

“.....The role of the communication and informatics sector in recording and reporting perinatal deaths is as a data guard whose task is to unify the data on perinatal deaths from related institutions or parties such as the PKK, the health office, the administrative village, and the population and civil registry. At present the information system in the city of Semarang is still being developed....."

\section{Development Model of Integrated Report- Record of Perinatal Death}

Based on the initial assessment of PDSR in Semarang City, it needs an integrative system that can integrate all data from the various stakeholder. The concept model that can be developed from the existing condition is:

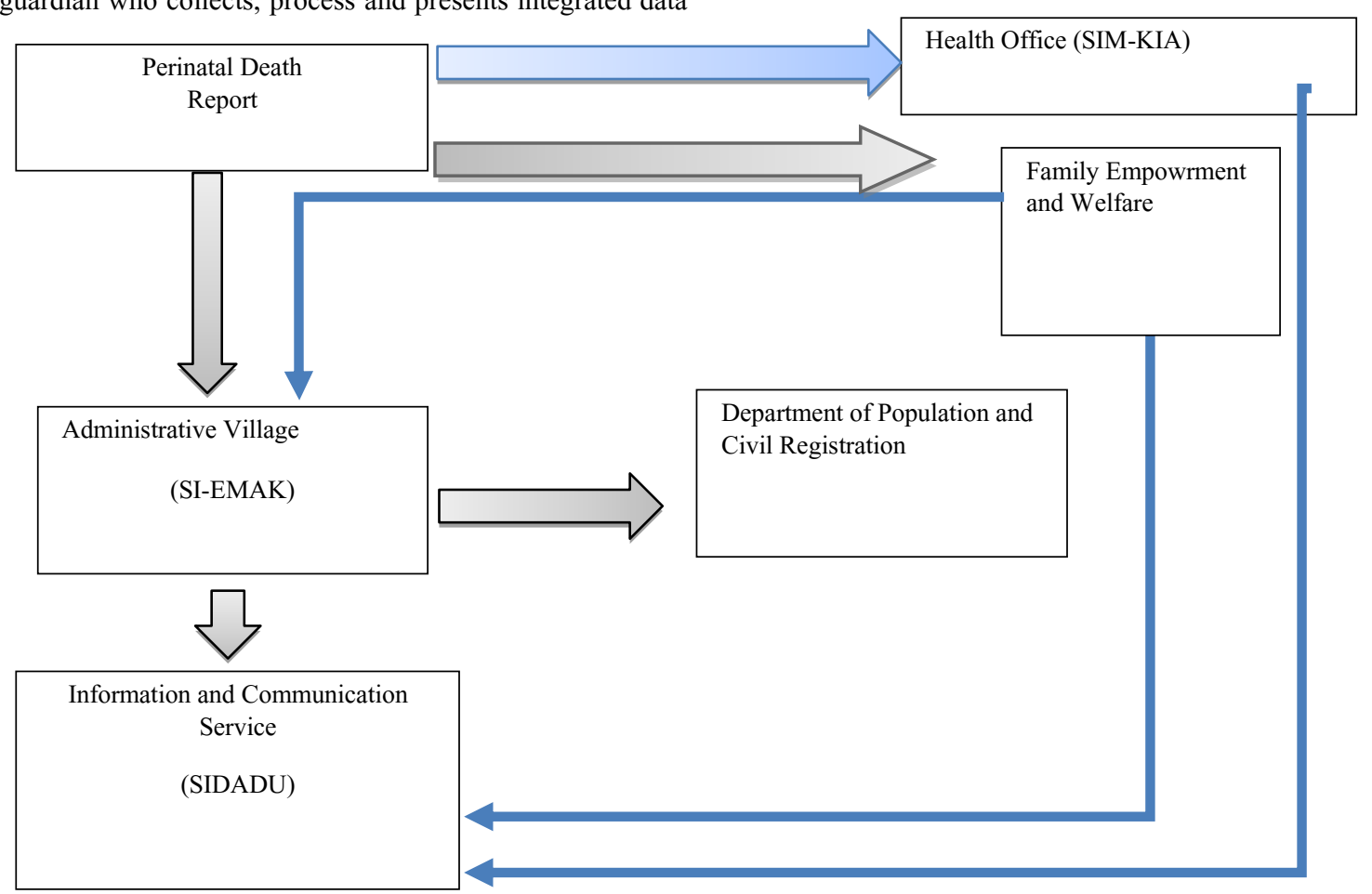

Diagram 1. Concept model or process of report and record perinatal death in Semarang City

In this model, principle way of report and record perinatal death through Health Office (SIM-KIA) and forward to Information and Communication Service (SIDADU). To obtain valid data, the Health Office should identify all health care facilities that serve labor and services to pregnant women

and encourage these health service facilities to report data on perinatal deaths to the Health Office.
Second way report and record perinatal death can be done through report and record through administrative village (SI-EMAK) system and forward to Information and Communication Service (SIDADU) and Department of Population and Civil Registration. Administrative village can receive data from Family Empowrment and Welfare or community. To support second way model there needs to be a Circular Letter concerning the notification of services regarding the recording and reporting of perinatal deaths in Administrative Village. There are also need Circular Letter to 
relevant government stakeholder such as Health Office, Department of Population and Civil Registration, Family Empowrment and Welfare, and also Information and Communication Service (SIDADU) to be active and synergize in the collection, monitoring, and evaluation of perinatal death data.

It also necessary to socialize the obligations and the importance of reporting perinatal death to community. Technical guidelines need to be formulated (can be in the form of a Mayor Decree regarding the Integrated Data Integration System (SIDADU) in general and the recording and reporting of perinatal deaths in particular. Based on the discussion of related stakeholder, there is a difference definition of perinatal death. Health Office says that perinatal death is newborn until 7 days, stiil birth and intrauterine fetal distress (IUFD) dont report as perinatal death but report as IUFD. This condition contradict with WHO definition says that " The perinatal period refers to 22 completed weeks ( 154 days) of gestation and ends seven completed days after birth." - So that, the agreement of perinatal death definition was needed because its the crucial point.

The integrated system of recording and reporting of perinatal deaths was also carried out by the Ministry of Health of the Republic of Uganda even though in a different form. The system for recording and reporting perinatal and maternal deaths (MPDSR) in the country is carried out through 3 ways, namely the health facility level, Integrated Disease Surveillance and Response (IDSR) Platform, and community level. ${ }^{?}$

At the health facility level, reporting is carried out through the National Health Maternal Information System (HMIS) and reported regularly every month. Data sources were obtained from maternity registers, gyanecology registers, operating theater registers, OPD registers, admission registers, discharge registers, ICU registers, postnatal registers, birth and death registers and the mortality register. Sources of data on perinatal deaths include registers in maternity, postnatal, newborn, special care units and or in the pediatric ward. ${ }^{8}$ In terms of integration of surveillance and response data (IDSR), Republic of Uganda conducts periodic reporting every week through mTRAC, an electronic surveillance platform which is then linked in DHIS2.

All deaths both maternal and perinatal deaths must also be reported by the community. The Ministry of Health Village Health Team Strategy recommends that members assigned to the Village Health Team (VHT) should record and report deaths that occur in their area. Then the supervisor or VHT coordinator reports the data to health facilities through the supervising Health Assistant. VHT is also required to report according to NIRA guidlines..,$\underline{11}$

Data integration is very useful for obtaining valid, real, and appropriate data in the community. This is because data integration will combine all aspects or data sources. The data can be processed and used as a basis for decision support. ${ }^{12,13}$

According to the Data Integration for Future Medicine (DIFUTURE), the integration of health data has three stages. ${ }^{14}$ First, data was inputted and standardized through technical and interface standards such as HL7, DICOM, and IHE profiles. ${ }^{14,15}$ Second, the data is processed, transformed, and classified to the data level. Third data will be imported to analytics platform and data models, so it will accesible in national level..$^{-}$

In data integration, data security and confidentiality are very important thing..$\frac{16}{}$ Data classification was needed to distinguish data type that can be shared..$^{17}$ For example in terms of causes of death in recording perinatal deaths. Individual data regarding the cause of death is sensitive data, so it cannot be shared and accessed by the community. However, common causes of perinatal death can be shared and accessed by community.

In addition, individual identities must be kept confidential. So that, data type that can be accessed through national is community data. $\frac{18}{-}$ This is in accordance with the Minister of Health Regulation in Indonesia Number 269 of 2008 on Medical Records and Minister of Health Regulation Number 36 year 2012 on Medical Secrets that states the obligation to maintain the patient's medical record even until the patient dies. ${ }^{19,20}$

Data security issues are very necessary. Cybersecurity needs to avoid cyberattack both of internal or external attack..$^{21}$ Data leakage can cause legal problems and contrary with applicable ethics. In addition, it is also necessary to periodically back up to avoid missing data. ${ }^{22}$ To support data integration, the government should implement a standard platform so that the standardization of integrated data is homogeneous..$\frac{23}{}$

In addition to the number of perinatal deaths, reporting on the cause of perinatal death in terms of population administration is debatable. This is because in the form of perinatal death reporting, there is a column of causes of death. Some stakeholders states that the cause of death should be an undisclosed matter and this report is needed in terms of health not as population data. Determining the cause of death is considered quite difficult because it requires a verbal autopsy and perinatal maternal audit so that it cannot be determined immediately.

In reporting the causes of perinatal deaths, several countries such as Australia have used the International Clasification of Diseases (ICD-10) adopted since January 1, 1999..$^{24}$ In 2016, the World Health Organization (WHO) issued an ICD-10 to death during the perinatal period (ICD$\mathrm{PM})$. In the guide, the procedures for issuing death certificates, ICD-PM usage, special conditions, and perinatal audits are explained. $\frac{25}{}$

The time of perinatal death is the only information captured at that time classify deaths in poor resource settings, where the burden of disease is the greatest. In this arrangement, data about time can be used to make international comparisons and programmed decisions to focus local efforts and interventions. Especially carry it joint birth and newborn death in standard definitions and coding systems. ${ }^{25}$

Not only rules that allow comparison, but also the use of ICD extensively (117 countries use it ICD for reporting deaths) has great potential to promote death previously unknown. ICD-PM is designed to be used for all antepartum, 
intrapartum and early neonatal deaths. Early neonatal mortality falls in the perinatal period as defined by ICD-10, and therefore it must always be classified using ICD-PM. $\frac{25}{-}$

\section{CONCLUSION}

Recording and reporting of perinatal death hasnt integrate yet in Semarang City, Indonesia. Therefore, a concept that integrated perinatal death data was needed. First, data comes from the Health Office that was reported to Information and Communication Service. Second, data comes from Administrative Village and Family Empowrment and Welfare and forwarded to Integrated Data Integration System (SIDADU) in Information and Communication Service is one of alternative integration. It also necessary to socialize the obligations and the importance of reporting perinatal death to community. Technical guidelines need to be formulated regarding the Integrated Data Integration System (SIDADU) in general and the recording and reporting of perinatal deaths in particular.

\section{ACKNOWLEDGEMENT}

Thank you to UNICEF for funding support and the Diponegoro University Institute for Research and Service who have supported the implementation of the PDSR program in Semarang City.

\section{REFERENCE}

1. Thomas SD, Hudgins JL, Sutherland DE, Ange BL, Mobley SC. Perinatal program evaluations: methods, impacts, and future goals. Matern Child Health J. 2015 Jul;19(7):1440-6.

2. Vanessa Brizuela and Ozge Tuncalp. Global initiatives in maternal and newborn health. Obstet Med. 2017 Mar; 10(1): 21-25.

3. Law Number 23 year 2006 on Population Administration

4. Joint Regulation between Minister of Home Affairs and Minister of Health Number 15 year 2010 and Number 162/MOH/PB/I year 2010 on Reporting of Deaths and Causes of Death

5. Mayors Regulation in Semarang City Number 40 year 2017 on Integrated Data Information System (SIDADU)

6. World Health Organization (WHO). Available from: https://www.who.int/maternal_child_adolescent/topic s/maternal/maternal_perinatal/en/, cited at 11 January 2019.

7. UGANDA. A Promise Renewed. Reproductive Maternal Newborn and Child Health Sharpened Plan for Uganda. 2013

8. Ministry of Health of Republic Uganda. Maternal and Perinatal Death Review. 2015
9. Ministry of Health of Republic Uganda. National Technical Guidelines for Integrtated Disease Surveillance and Response. 2011

10. Ministry of Health of Republic Uganda. Village Health Team. Strategy and Operational Guidelines. 2010

11. World Health Organization (WHO). Maternal Death Surveillance and Response. Technical Guidance. Information for Action to prevent maternal death.

12. Greens RA, editor. Clinical Decision Support : the road to a broad adoption. Oxford : Academic Press; 2014

13. Enea Parimbelli, Lucia Sacchi, and Riccardo Bellazzi/ Decision Support through Data Integration : Strategies to Meet the Big Data Challenge. EJBI. 2016. ; 12.

14. Fabian Prasser, Oliver Kohlbacher, et al. Data Integration for Future Medicine (DIFUTURE). Thieme Medical Publishers.2017

15. Bender D, Sartipi K. HL7 FHIR : An Agile and RESTful approach to healthcare information exchange. 26th IEEE International Symposium on Computer-Based Medical Systems. 2013:326-331

16. Ponemon Institute. Big data anaylitics in cyber defense. Research Report, EB-7499.02.13. February 2013. Pp: 1-31

17. S.Crawford, D.Piesse. Cyber insurance, security and data integrity, Part 1: Insights into cyber security and risk-2014. Techincal Report, Ernst \& Young LLP

18. A.A. Cardenas, P.K. Manadhata, S.P. Rajan. Big Data Analytics for Security. IEEE Security and Privacy. 11(6), 2013, pp: 74-76

19. Minister of Health Regulation in Indonesia Number 269 of 2008 on Medical Records

20. Minister of Health Regulation in Indonesia Number 36 year 2012 on Medical Secrets

21. Lidong Wang and Cheryl Ann Alexander. Big Data in Distributed Analytics, Cybersecurity, CyberWarfare, and Digital Forensics. Digital Technologies. 2015. Volume 1 (No.1): 22-27

22. G. Grubor, I. Barac. Integrated Proactive Forensic Model in Network Information Security. Singidunum Journal of Applied Scienes. 2014. Pp. 693-699

23. Peleg M. Computer-interpretable clinical guidelines : A methodological review. JBI. 2013. Augustus : 46 (4) : 744-63.

24. Australian Beureau of Statistics. Perinatal Death, Australia. 2009.Available from : http://www.abs.gov.au/AUSSTATS/abs@.nsf/Looku p/3304.0Explanatory\%20Notes 12007?OpenDocumen $\mathrm{t}$

25. World Health Organization. 2016. The WHO application of ICD-10 to deaths during the Perinatal 
Period : ICD-PM. Available from : https:/www.who.int/reproductivehealth/publications/ monitoring/icd-10-perinatal-deaths/en// 